\title{
6
}

\section{At home in the fens with the Grendelkin'}

\section{Christopher Abram}

In his 1914 book Vampires and vampirism, Dudley Wright wrote that 'there is an Anglo-Saxon poem with the title $A$ vampyre of the fens' ${ }^{2}$ You can hardly imagine how excited I was to read this: one comes across new Anglo-Saxon poems so rarely, and rarer still are compositions with such juicy titles. A vampyre of the fens, with its ring of the slightly schlocky Gothick shocker, would have been an unexpectedly thrilling addition to the canon. Alas, $A$ vampyre of the fens is found nowhere in the Anglo-Saxon Poetic Records (the standard edition of the Old English verse corpus), and the usual works of reference are silent on the subject. I needed more information about this mysterious text. Turning to Brian J. Frost's classic of popular vampirology, The monster with a thousand faces, I found some. According to Frost, $A$ vampyre of the fens is an obscure (no kidding) Anglo-Saxon poem, written at the beginning of the eleventh century. This poem, he claims, marks the first appearance of a vampire in a work of pure imagination. ${ }^{3}$

'Pure imagination' is, of course, right, in that this poem is entirely imaginary. There is no such poem as $A$ vampyre of the fens. Frost is passing on unscrutinized Wright's assertion - and there are other vampirological treatises that repeat the claim. ${ }^{4}$ Thanks to the detective work of Eugenio Olivares Merino, we now know that the ultimate source of the idea of a lost Anglo-Saxon vampire tale is found in Charles Dickens's Household words magazine where, in 1855, Edmund Ollier introduced it to the world, in terms that Wright would borrow wholesale: 'There is an old Anglo-Saxon poem on the Vampyre of the Fens', he wrote. $^{5}$ Ollier was an all-purpose hack with no knowledge that we can ascertain of early medieval literature and culture - the trail ends with him, though Olivares Merino speculates that Ollier may have been influenced, probably indirectly, by a reference to Beowulf in Jacob Grimm's Deutsche Mythologie. Grimm made the connection between Grendel and a vampire for the first 
time in scholarship. ${ }^{6}$ Grendel, writes Grimm, sucks blood from the veins of his victims - that much is certainly true; he does so quite explicitly in line 742b of the poem: blod edrum dranc. ${ }^{7}$ In the same passage, Grimm speaks of Grendel's dwelling in swamps and marshes. And so, perhaps, 'the vampire of the fens' was born. It seems likely, therefore, that Ollier was referring to Beowulf, a poem that he didn't know but had heard tell of, possibly from somebody familiar with Grimm's work. Dudley Wright then gave a title to Ollier's imaginary poem, after which The Vampyre of the Fens became what Olivares Merino calls a 'bibliographic ghost', a false echo of a song that was never actually sung. ${ }^{8}$

It's a shame, because The Vampyre of the Fens is potentially a splendid title for the poem we know as Beowulf, or at least for that part of the poem that takes place in Denmark. We must always remember that the title Beowulf, as solid and definitive and obvious as it is, is an invention of modern antiquarianism. We have no idea what the Anglo-Saxons called this poem - or even if any of them ever read it. (The two scribes responsible for copying Beowulf into London, British Library, Cotton Vitellius A. xv certainly processed its text, but we might question to what extent and in what manner they were reading it.) Thinking about alternative titles for Beowulf can be a productive way of destabilizing our comfortable preconceptions about the poem. If Beowulf were called A Vampyre of the Fens, the murderous monster Grendel would appear to be more central to the narrative's design - perhaps we might even try to imagine Grendel as the poem's protagonist, rather than as an always Othered antagonist to Beowulf and the men of Heorot, which is the name given to the Danes' newly built hall, which Grendel attacks murderously. The new title can also conjure a sense of place that might be hermeneutically productive in reading the poem, leading us on a journey into a particular type of landscape - a wetland environment in which Grendel is intimately embedded.

The Old English poem Maxims II states that 'pyrs sceal on fenne wunian' (a pyrs shall [or must] live in a fen), as if this were something everybody knew:

God sceal on heofenum,

dæda demend. Duru sceal on healle, rum recedes muð. Rand sceal on scylde, fæst fingra gebeorh. Fugel uppe sceal lacan on lyfte. Leax sceal on wæle mid sceote scriðan. Scur sceal on heofenum, 
winde geblanden, in pas woruld cuman.

peof sceal gangan bystrum wederum. byrs sceal on fenne

gewunian

ana innan lande. ${ }^{9}$

(God must be in the heavens, the judge of deeds. A door must be on the hall, the building's open mouth. A boss must be on a shield, firm protection for fingers. A bird must soar in the air on high. A salmon must glide in the pool, darting about quickly. The rain must be in the heavens, mixed with the wind, to come upon this world. A thief must travel in dark weather. A pyrs must dwell in a fen, alone in the land.)

A pyrs shall live in a fen: it is as much his habitat as the pond is the salmon's or the wood is the wild boar's or the kingdom is the king's. Such is the natural order of the world. Or perhaps we should take sceal as imperative: a pyrs must live in a fen, where it will be alone in the land. The fen is the space apportioned to these creatures, whether by man, God, or fate, and they must not live anywhere else. It would not be natural. Why? What happens when a pyrs leaves the fen?

We know very well what happens, because Grendel is a pyrs. Beowulf says so, in his first speech to Hrothgar: 'Ond nu wið Grendel sceal, / wið pam aglæcan ana gehegan / ðing wið pyrse’ (and now I must seek a meeting alone with Grendel, the terrible adversary, the pyrs) (424b-426a). The poem gives us no clue what a pyrs is - but Grendel is one. ${ }^{10}$ And we know, too, that Grendel conforms to type in his habitat, whether because of his nature, by choice, or by compulsion. Grendel's home in the fens is one of the first things we learn about him: this information is given the very first time that we hear the monster's name.

Swa ða drihtguman dreamum lifdon,

eadiglice, oð ðæt an ongan

fyrene fremman feond on helle;

wæs se grimma gæst Grendel haten, mære mearcsteapa, se pe moras heold, fen ond fæsten; fifelcynnes eard wonsæli wer weardode hwile. (99-105)

(Thus the warriors lived in joy, happily, until a fiend in hell began to commit an atrocity. The grim guest was called Grendel, the famous march-stepper, he who held the marshes, fen, and fastness; the unfortunate man guarded for a time the homeland of the kindred of monsters.) 
Grendel occupies a very particular landscape: it is a border territory, a mearc; it is a mor, which it is almost impossible to persuade Beowulf translators is not directly equivalent to moor in modern English usage, with its windswept, hilly, and romantic Wuthering Heights connotations. Rather, mor can (and here, should) refer specifically to swampy waste ground, a morass: it is recorded as such in the Old English Life of Guthlac, the Old English Hexateuch, and in an early Aldhelmian gloss, and remains so in the moors of Somerset, ancient marshlands that have long since been drained. Although there are also Anglo-Saxon attestations of mor as meaning a desolate high place, to translate as 'moor' when 'marsh', 'mire', and 'morass' are available to us seems like an infelicity in this instance, since mor is so closely collocated with fenn in this passage. ${ }^{11}$

A fenn is a fen, which is to say that it is a place that is somewhat watery, somewhat muddy, pretty much flat - difficult territory to live in, unsuitable for farming, hardly land at all, but something marginal and transitory. Like all wetlands, fenland is hard to pin down, hard to categorize. As William Howarth puts it:

\begin{abstract}
We cannot essentialize wetlands, because they are hybrid and multivalent: neither land nor water alone, they are water land; a continuum between terra and aqua. In rhetorical terms they are not syntax but parataxis, phrases placed side by side, without apparent connection, a term Joseph Frank used to describe spatial forms that evoke a great variety of response. In their wildness, wetlands dispossess readers of old codes and lead toward new syntax, where phrases may begin to reassemble. ${ }^{12}$
\end{abstract}

Fasten, however, carries with it the idea of a place of security or sanctuary: somewhere that can shelter one - a home that can be a castle. Not everybody can, must, or would wish to live in the fen: it is the fifelcynnes eard, the home or land of a race of monsters specifically, a race of aquatic monsters, as all occurrences of fifel in Old English poetry refer to creatures that live in or around bodies of water. ${ }^{13}$ Grendel is practically and perhaps actually amphibious. His dwelling-place is underwater, or at least has to be entered via a long and arduous swim. It is difficult to get to, just as the fens have traditionally been regarded as one of the most inaccessible landscapes of England. Its remoteness and inaccessibility makes the fen a place of refuge for Grendel and his mother: as well as a feesten, we hear the mere described as a fen-freodo (851b), a fen-hop (764a), and a mor-hop (450a) - a 'sanctuary' and a 'refuge' twice over. The first two of these instances might be ironic, since they 
both refer to the fen as a sanctuary for the mortally wounded Grendel - the fen becomes the monster's resting-place, his mausoleum. Once he has left the fastness of the fens, they can no longer protect him from the likes of Beowulf, but the fens are nonetheless Grendel's true homeland, his family's eard. The Dictionary of Old English glosses the occurrence of eard at Beowulf 104b as 'habitat', which has the advantage of emphasizing the symbiotic relationship between the Grendelkin and their oikos, though it also runs the risk of aligning them more closely than necessary with the 'natural', the 'animal', the 'wild'. ${ }^{14}$ Grendel returns home to his proper habitat, his real home, to die.

In other Old English poems, the eard is often the place one is exiled from, but for Grendel it is the place he is exiled to - and this place of exile becomes a new home. ${ }^{15}$ Grendel is a mearcstapa, but he is not an eardstapa like the Exeter Book's exilic Wanderer, who is characterized by a restless rootlessness as he trudges over land and sea: deprived of a home with God or among men, Grendel and his kin have found a new eard, a habitat in the fens that suits them, a place which they have settled. ${ }^{16}$ And this homeland is God-given or at least God-sanctioned: Hrothgar, the Danish king whose realm has been ravaged by Grendel's attacks, acknowledges (1724b-1726) that it is God himself who apportions eard to people, along with wisdom and nobility (snyttru and eorlscipe).

As it happens - and I hope this is the only characteristic I share with Grendel - the fens are also my homeland, my eard. I have lived most of my life on the edge of the low-lying, marshy plains of Lincolnshire and Cambridgeshire. (When I moved to northern Indiana, I discovered a landscape that had once been another major wetland habitat and had since been drained for agriculture; it is possible that this explains why I quickly came to feel at home there.) I am writing this chapter in Little Downham, three miles from Ely, whose magnificent cathedral, the so-called 'ship of the fens', can be seen clearly from the edge of the village. Here, we are on solid ground, rather than down in the mire itself; Downham derives its name from Old English dun-ham, 'hill settlement', and the older name for the village is Downham-in-the-Isle, for once upon a time we would have been surrounded here on three sides by marshland that flooded regularly in winter and remained distinctly boggy the whole year round. ${ }^{17}$ To this day, the road between the nearby towns of Littleport and Wisbech is normally closed for weeks each winter when the Great Ouse overflows its banks and returns this part of the fens to something like its original landscape - a great silver 
expanse of water broken here and there by half-submerged scrub trees, populated solely by wildfowl. Little Downham, like Ely itself, is something of a 'fen-sanctuary', though not the same type of refuge as Grendel seeks; it is a place of refuge kept apart from the rest of the world by the fens that surround it, but it is also a place of refuge from the fens and from whatever lurks in them.

My fens are not the Anglo-Saxon fens - few British landscapes have changed as substantially over the past thousand years - but there is still a shock in hearing this landscape collocated with the abode of a monstrous race, in the possibility of an unthought-of exoticism around a bend in the road. But after the initial shock has worn off, I find myself admitting that there is still something uncanny about this corner of the world, something never quite settled or wholly stable about it. These fens are no longer wetlands, but they are still a landscape of featureless expanses, of a disorienting lack of landmarks, a landscape in which roads proceed in dead straight lines for miles before haring off at right-angles for no apparent reason. Drowning is one of the most common causes of death in road accidents around here. On a foggy night in the fens it is still quite easy to imagine Grendel creeping up the hill to the village under cover of darkness, looming out of the thick, white mist, and appearing at the window. There could well be something 'out there' in the fens, precisely because the fens still feel so powerfully 'out there' - so alien, so unwelcoming. Grendel's entrance in the poem - one of the most effectively terrifying passages in all literature, to my mind - is all the more spine-chilling when I read it in the fens, and as a fenlander. Grendel comes out of a particular landscape, and this landscape is, at least in part, what makes him what he is.

By the time we see Grendel, some seven hundred lines into Beowulf, we have already heard plenty about him. The narrator speaks of him, Beowulf speaks of him, Hrothgar speaks of him. We have learned of Grendel's origin among the kindred of Cain, and his ravages have been described. We have seen Heorot cleared for the night and entrusted to its new guardian, Beowulf. But for all the information we have already received about Grendel, nothing can prevent his arrival from shocking us:

Com on wanre niht

scriðan sceadugenga. Sceotend swæfon,

pa pæet hornreced healdan scoldon,

ealle buton anum - pæt wæs yldum cup

pæt hie ne moste, ba metod nolde,

se scynscapa under sceadu bregdan - 
ac he wæccende wrapum on andan

bad bolgenmode beadwa gepinges.

Đa com of more under misthleopum

Grendel gongan, Godes yrre bær;

mynte se manscaða manna cynnes

sumne besyrwan in sele pam hean.

Wod under wolcnum to bæs pe he winreced,

goldsele gumena gearwost wisse,

fætum fahne. Ne wæs pæt forma sið

pæt he Hropgares ham gesohte;

næfre he on aldordagum, ær ne sipðan,

heardran hæle healðegnas fand.

Com ba to recede, rinc siðian,

dreamum bedæled. Duru sona onarn,

fyrbendum fæst, sybðan he hire folmum æthran;

onbræd ba bealohydig, ða he gebolgen wæs,

recedes mupan. Rape æfter bon

on fagne flor feond treddode,

eode yrremod; him of eagum stod

ligge gelicost leoht unfæger. (702b-727)

(The shadow-walker came striding in dark night. The warriors slept, those who were supposed to guard the gabled house, all but one people knew that the hostile foe couldn't draw him into the shadows, if God didn't wish it - but awake he waited, swollen-hearted, to meet the wrathful soul in battle.

Then came from the marsh Grendel, walking under misty slopes, bearing God's wrath. Mankind's assailant thought to seize someone in the high hall. He waded in the shadows, beneath the clouds, until he could perceive the men's gold-hall as clear as day, adorned with decorations. It wasn't the first time that he had sought out Hrothgar's home; never, before or after, in all the days of his life, did he find a harder fortune among the hall-thegns. The warrior came travelling to the hall, deprived of joys. The door, fast with forged bands, soon gave way when he touched it; the evil-minded one broke open the mouth of the hall because he was swollen with rage. Straight away the fiend stepped on to the decorated floor: he went angrily. From his eyes shone a light most like an unpleasant flame.)

This passage is justly famous for its terrifying affect. ${ }^{18}$ The threefold repetition of com $(702 \mathrm{~b}, 710 \mathrm{a}, 720 \mathrm{a})$ evokes the deliberate, inexorable approach of the killer, which is intercut with images of the Danes sleeping unawares and Beowulf keeping his solitary vigil. Grendel is initially called sceadugenga here, a 'shadow-walker' - one of his most impressionistic epithets in the poem, emphasizing his 
crepuscular creepiness as he advances on wanre niht. His arrival at Heorot is chilling regardless of where he came from, but reading Beowulf in a fenland setting adds a particular piquancy to lines 710-11, when we read mor as 'marsh': 'Pa com of more under misthleopum / Grendel gongan, Godes yrre bær' ('Then came from the marsh Grendel, walking under misty slopes, bearing God's wrath).

Those of us who dwell 'in the fens' for the most part dwell out of the fens, in fact, on the little patches of higher, drier ground like the isle upon which Little Downham was founded. The preponderance of settlement names ending in the -ey (Old English -eg, 'island') suffix around here - Coveney, Ramsey, Stuntney, Whittlesea, and so on - indicates as much. Before they were drained, the fens proper - the marshes themselves - were thought by outsiders largely unsuitable for human habitation, though, as Susan Oosthuizen has shown, even in the early medieval period this landscape was never entirely uninhabited, never as empty as people thought. ${ }^{19}$ People could make their livelihoods from the fens - as fishermen or reedcutters, perhaps - but they preferred to cluster together on the islands; they still do so today, even though arable farmland is all that separates one village from the next. The fact that Grendel comes of more is perhaps a special source of horror when we read about it in this precise spot, since it is the mor which surrounds us here. As a child, I lived on Moor Lane, a road which led down to Bardney Fen from the village of Potterhanworth near the northern extremity of the Lincolnshire fens. (I always wondered why it was called moor lane, since at the time I imagined moorland as being a barren upland environment.) I know what it is like to watch a winter fog-bank roll up the slopes of our modest escarpment and swallow the village's houses one by one until only the soft penumbra of electric lights are visible down the street. In the imagination, as well as in fact, mists are a climatic phenomenon that is inseparable from this type of landscape: in 1627 the cartographer John Speed wrote that, in Lincolnshire, 'the Ayre upon the East and South part is both thicke and foggy, by reason of the Fennes and unsolute grounds', an image that had sufficient traction for Shakespeare to have King Lear speak of 'fen-sucked fogs drawn by the powerful sun'. ${ }^{20}$ Grendel is coming, coming, coming up from the fen, up the slopes, under the cover of mist and darkness. He is coming out of his space into ours.

Grendel's ability to move between worlds - from water to land, from his own monstrous parody of a hall to Heorot's all-too-human 
parody of a hall, perhaps from hell to earth and back, from the wilderness to civilization - is one of his most defining features, encapsulated in his being called mearcstapa (103a and 1348a, where Grendel's mother is included in the plural of the term). Mearcstapa is found only in Beowulf, and it is applied only to Grendel and his mother: it is not one of the many epithets shared by the monsters and the poem's hero. The mearc is a borderland, an area between places that manages to be something of both places at once but wholly of neither, establishing the limits of a community's conception of itself. As Lindy Brady puts it, 'More importantly than its precise location ... a mearc connoted the space just beyond the utmost control of a society that marked the difference between "us" and "them"., ${ }^{21}$ While the most famous mearc-derived place name in the British Isles is found in the so-called Marches that form the contested buffer zone between England and Wales, it is also easy to read the East Anglian fens as another mearc, not least because the Cambridgeshire market town of March derives its name from this term.

March is built on yet another island in the fenland swamp. It is not clear why this place in particular should be named after its liminal position when the fens are everywhere and always a liminal landscape, their borders undefined and their limits constantly shifting. ${ }^{22}$ The route of a Roman causeway passes close to March, so perhaps it was perceived as having a position on the margins of navigable space in the area. Not too far away is found a second trace of the Romans' interactions with the fens - the Car Dyke, an 85-mile-long artificial ditch that limns the western edge of the fens. The Car Dyke can be seen as marking the limit of terra cognita in this part of the Roman world: a symbolic border, if not much of an actual defensive structure. March, and the mearc, is thus beyond the limits of the civilized, or truly civilizable, world. The landscape across which the mearcstapan travel in Beowulf is in a similar position relative to the built environment of Heorot and all it stands for. The fen in Beowulf is an out-space as defined by Heorot's in-space. Heorot is a centre; the fen is a periphery. We know that Heorot is not far from Grendel's home by measure of miles ('Nis pæt feor heonan / milgemearces pæt se mere standeð') (1361b-1362), but the two locations are worlds apart. The road from the coast to Heorot is stanfah (paved with stones) (320a) in the Roman manner, while Heorot itself is 'timbred / geatolic and goldfah' (constructed splendidly and with golden adornments) (307b-308a). These descriptions can be contrasted with the landscape evoked by 
Hrothgar's fullest description of the environment that the monsters occupy:

Hie dygel lond

warigeað, wulfhleopu, windige næssas,

frecne fengelad, ðær fyrgenstream

under næssa genipu niper gewiteð,

flod under foldan. Nis pæt feor heonon

milgemearces bæt se mere standeð;

ofer pæm hongiad hrinde bearwas

wudu wyrtum fæst wæter oferhelmað. (1357b-1364)

(They occupy a secret land, wolf-inhabited slopes, windy headlands, a perilous fen-path, where a mountain stream goes down in mist underneath the crags, a torrent under the earth. It is not far from here, measured in miles, that the mere lies; above it hang frost-bound groves: the wood, fixed by its roots, overshadows the water.)

This passage has been controversial because it seems to collocate geographical features that we would not expect to find in a single location. The way to the monsters' home is called a fengelad (watery passage across a fen), and the modern English descendant of gelad, 'lode', is ubiquitous in the fens as a name for a dyke or other minor watercourse. ${ }^{23}$ But there are other features in this passage that seem to suggest a different type of landscape, perhaps a coastal region. I do not think that wulfhleopu (wolf-slopes) presents a particular problem: we have seen that Grendel comes up from below misthleopu, and the wolfishness of these slopes now marks them out as the land of hostile outlaws, ${ }^{24}$ without prejudice to where the mere is actually located. ${ }^{25}$ The repeated references to nossas (headlands) do not seem to belong in a fenland setting, since the place-name element -ness is found exclusively around the sea-coasts of England, and not in the East Anglian fens. But there are promontories in the fens, those shallow islands and spurs of higher ground between them that in places allowed passage across the undrained fens without the use of a boat. For example, the small town of Ramsey, famous for its Anglo-Saxon monastic foundation, though named as if it were an island, is in fact situated on a narrow headland that projects out into the fens. Since Ramsey stands at the end of a gentle decline at an altitude of only about seventeen feet above sea level, it is hardly the sort of landscape feature we are accustomed to think of when we think of a ness; but in a fenland context, a change in elevation of only a few feet can be highly significant, as it takes one out of the mire back on to terra firma, or vice versa. 
Fyrgenstream probably means 'mountain stream', and mountains are a landscape feature that the fens most definitely lack. Other aspects of Hrothgar's description, however, retain something more distinctively fennish. In particular, the phrase 'flod under foldan' (water under earth) conjures up an image of sodden marshland: the streams that flow down from the higher ground have to end up somewhere, and here we may imagine them seeping slowly into the swamp. And the trees overhanging the water would also suggest an inland lake, perhaps, more than a windswept coastal headland; at any rate, this landscape is indistinct, neither one thing nor another, and while this lack of definition may indicate - as several scholars have claimed - that this passage is a literary confection, or even simply 'a metaphor for terror', ${ }^{26}$ the fens themselves are - in both reality and imagination - a landscape between other types of landscape, a landscape that confounds categorical identification. The use of the term mere for the body of water in question may itself be relevant to this discussion: though 'mere' is a perfectly ordinary word for a pond or lake, it was also applied, prior to their draining in the seventeenth century, specifically to the larger, permanent lagoons in the Cambridgeshire fens at (for example) Whittlesea, Ramsey, and Soham. ${ }^{27}$ Bodies of water outside the fens can be called meres, but in these fens, it seems as though areas of standing water can only be called meres.

Hrothgar has more to say about Grendel's abode:

Pær mæg nihta gehwæm niðwundor seon,

fyr on flode. No pæs frod leofað

gumena bearna pæt bone grund wite.

Đeah pe hæðstapa hundum geswenced, heorot hornum trum holtwudu sece, feorran geflymed, ær he feorh seled, aldor on ofre, ær he in wille, hafelan beorgan; nis pæt heoru stow. (1365-72)

(There each night a fearful wonder may be seen: fire in the water. There is no one alive among the children of men so wise as to know the bottom. Though the heath-stepper, the strong-horned hart, pursued by dogs, chased a long way, might seek the forest, he would give up his life rather than go in[to the mere] to save his head: it is not a pleasant place.)

The 'hateful wonder' that Hrothgar reports, the fyr on flode (fire in/ on the water) visible from the shore at night, has been interpreted in 
a way that could have a particular significance to a fenland reading of Beowulf. Though the interpretation has long since fallen out of fashion, William Witherle Lawrence's solution to the conundrum of what we should understand fyr on flode to mean takes us straight back to marshland: Lawrence regarded this peculiar luminescence as an image of a 'will o' the wisp that haunts marshy places', the result, in biological terms, of an emanation of swamp gases. ${ }^{28}$ This phenomenon, also known as ignis fatuus (foolish fire), has been absorbed into folklore traditions wherever boggy ground is part of the landscape. If the fyr on flode were supposed to represent a will o' the wisp, it would tell us that the mere and its environs include wetlands as well as open water, as the methane thought necessary to produce ignis fatuus must come from substantial peat deposits. People's inability to discern the bottom of the mere could also be a consequence of a high proportion of organic matter in the water, as is typical of bogs, which have often been perceived as 'bottomless'. 29

Similarly, the famously reluctant hart, which would rather die at the hands of its pursuers than leap into the mere, reflects the anxiety that outsiders have sometimes felt upon encountering the alien landscape of the fenland. ${ }^{30}$ Perhaps the deer is reacting atavistically to the evil that permeates this heoru stow; perhaps it cannot swim; perhaps it is understandably anxious about the possibility of getting stuck in a bog. In any case, the hart does not belong there, as the epithet hœðstapa may indicate: as a hœðstapa, the stag properly belongs to the heath, an upland area, as well as to the holtwudu, the forest - another geographical feature not found in a fenland setting. Beowulf's hart has a home on the heath, in an animal realm that is home neither to humans nor the likes of Grendel. The monsters belong in the mere, the pyrs in the fen. The Danes do not belong in any of these spaces by right or custom or nature: they believe that home is where the Heorot is, but there are limitations on where heorots can go, which borders they can transgress. Andy Orchard is surely correct to note that the terrified hart at the side of the mere 'cannot help but conjure images of the imperiled Danish hall, Heorot' ${ }^{31}$ Both the hall and its animal avatar are in the wrong place.

About the precise location of Heorot we learn relatively little in Beowulf; less, in fact than we learn about the landscapes in which either the Grendelkin or the dragon live. We know that Heorot is in Denmark, that it is a short march from the coast. And we know 
what sort of building it is and why it was constructed, which also tells us that Heorot has not always been there, wherever 'there' is:

Pa wæs Hroðgare heresped gyfen,

wiges weorðmynd, pæt him his winemagas

georne hyrdon, оðð pæt seo geoguð geweox,

magodriht micel. Him on mod bearn

pæt healreced hatan wolde,

medoærn micel men gewyrcean

ponne yldo bearn æfre gefrunon,

ond pær on innan eall gedælan

geongum and ealdum swylc him God sealde,

buton folcscare ond feorum gumena.

Đa ic wide gefrægn weorc gebannan

manigre mægbe geond bisne middangeard,

folcstede frætwan. Him on fyrste gelomp,

ædre mid yldum, pæt hit wearð eal gearo,

healærna mæst; scop him Heort naman

se pe his words geweald wide hæfde. (64-79)

(Then Hrothgar was given success in war, glory in battle, so that his comrades eagerly obeyed him, until the young men grew into a large band of young retainers. It came to his mind that he wanted to command people to build a hall, a great mead-hall, one that people's children will hear of forever; and there to distribute everything which God had granted him with young and old - apart from ancestral land and men's lives. Then - as I have heard tell - work was commanded from far and wide, from many peoples throughout the world, to adorn the people's dwelling place. It came to pass quickly for him: it was all finished in haste by the people, the greatest of halls; he called it Heorot, he whose words had power far and wide.)

Heorot is a new building, inhabited for less than a generation before Grendel's attacks begin, and destined to burn not far into the future (83b-85). Presumably Hrothgar did not know in advance that his chosen site lay close by a lair of monsters of the kindred of Cain; though if he had known, he might not have cared, since Heorot functions mostly as a symbolic monument to the price one pays for hubris. (It certainly does not work very well as an actual stronghold that one can defend against enemies, unless a preternaturally strong hero turns up to do this job for one.) Heorot is a projection of Hrothgar's power and wealth - it literally gleams with gold. But what does it project that power onto? In a reading of Beowulf that foregrounds the importance of the wetland landscape that Grendel and his mother inhabit, I am inclined to see Heorot as encroaching 
on a landscape to which it can never belong - as trying to impose a symbolic order on to an ecological order with which it is utterly incompatible. As Alfred K. Siewers puts it, 'Heorot is constructed as an island of civilization ... confined and hemmed in by the powers of chaos', but perhaps strangely for an avowed ecocritic, Siewers does not problematize the binary between 'civilization' and 'chaos', which also encodes a human/nature dichotomy that is always constructed, never natural. ${ }^{32}$ From the point of view of the 'civilized' reader, Heorot is a light shining in the darkness; Grendel is the darkness comprehending it not - not that Grendel does not understand Heorot so much as reject it, with all its noise and good cheer and stories of the God who has cast out Grendel's family, giving them as their eard a landscape that would be considered unfit for human habitation:

Đa se ellengæst earfoðlice
prage gepolode, se pe in pystrum bad,
pæt he dogora gehwam dream gehyrde
hludne in healle. Pær wæs hearpan sweg,
swutol sang scopes. Sægde se pe cupe
frumsceaft fira feorran reccan,
cwæð pæt se ælmihtiga eorðan worhte,
wlitebeorhtne wang, swa wæter bebugeð,
gesette sigehrepig sunnan ond monan,
leoman to leohte landbuendum (86-95)

(Then the ellengast suffered grievously for a time - he who dwelled in darkness - when every day he heard joy, loud in the hall. There was the sound of the harp, the clear song of the scop. One who knew how to recount from long ago the creation of people said that the Almighty made the earth, the beautiful plain that the water surrounds; the victorious one set the sun and moon as lamps to give light to land-dwellers.)

In the creation story whose performance bothers Grendel so much, we hear that God has made the sun and moon 'leoman to leohte landbuendum' (as lamps to give light to land-dwellers) (95). But Grendel and his mother are not land-dwellers, and their watery home has to be illuminated by uncanny means; ${ }^{33}$ they are benighted from the outset.

I am intrigued by the idea that Heorot is something ecologically malevolent, something alien, something out of place. It is a brilliant folly, an extravagant excrescence, the gin-palace of a nouveau-riche arriviste, a McMansion. It sticks out like a sore thumb; it is a blot 
on the landscape, and we know that it will not endure. Heorot is, presumably, built on the edge of the fen, or on an island in the fen; Grendel's mere is not very far from Heorot, though the paths between them can be difficult to follow. The two locations are part of the same landscape. When Grendel comes up from the mor, he is upon the hall almost at once. So, while Grendel trespasses in Heorot when he comes out of his marsh, the construction of Heorot might be read as an act of trespass in its own right. For the fen is Grendel's domain, as a member of the fifelcyn, and God's condemnation of Cain's line to exile includes the stipulation that they should be banished far from mankind: 'ac he hine feor forwræc, / metod for by mane mancynne fram' (but the creator condemned him to exile for this crime, far from mankind) (109b-10). The construction of Heorot, this temple of bling and braggadocio, has brought mankind into close proximity with Grendel's homeland. It is Hrothgar, by this reading, who first transgresses the spatial proprieties of the region. ${ }^{34}$ God's restraining order demands that Grendel should live far from people - but people are now right there, impinging on the space that is his by right. They made the first move: the Danes are the space invaders, and Grendel becomes an agent of resistance against a colonizing power.

The fens have often been a space in which resistance can be fomented. As well as offering sanctuary to those who, for whatever reason, cannot live in a 'civilized' in-space, this region has a long history as a locus of struggle against external oppression in many forms. Most famously, perhaps, in Cambridgeshire we have stories of Hereward the Wake, an exiled Anglo-Saxon nobleman who resisted Norman hegemony in the fens between Ely and Peterborough. In the doubtfully reliable narratives of Hereward's career, we see him, for example, escaping from the siege of Ely by leading his followers off the island and into the fenland's interior by secret tracks unknown to the colonialist interlopers..$^{35}$ Around 1070, this marginal landscape became for a moment a last enclave of pre-Norman England, precisely because the fens are so inaccessible to outsiders. The land there is impassable and impossible for those who have not adapted to its demands. The Normans failed in a direct assault on Ely because their warhorses and armour were too heavy for a wooden causeway across the fen to bear, for example. ${ }^{36}$

So, to oppressive external forces, the fens are a problem, because they harbour outlaws, freedom fighters, and monsters. This problem can only finally be solved through a wholesale redevelopment of the landscape. We might think of this in religious terms, first of 
all, and consider the way in which Ely Cathedral, the 'ship of the fens', looms over the marshes, prominent on its prominence, guiding travellers on to the island and sinners towards redemption. Instead of pursuing the tricksy will o' the wisp to our doom in a bog, today we can look for the light of the cathedral's great octagonal lantern to lead us to safety, to guide us home off the fen. It was the vision of the cathedral as a beacon on foggy autumn nights that first put me in mind of Heorot's relationship to Grendel's fenland - a building that symbolically imposes a new and alien value system on to the landscape. Like Heorot, Ely Cathedral appears as an island of cheer, security, and civilization in a sea of darkness - few places so close to significant human populations in the British Isles seem as dark as the fens at night.

But if this Christianization of the landscape fails to convert it from a monstrous, pagan wilderness into something a little more salubrious and easier to control, one can pursue other strategies in attempting to manage and tame the fens. One such strategy is to marginalize and stigmatize this world, emphasizing its distance from and opposition to 'civilization' by developing its associations with the supernatural, the evil, and the uncouth. Another, more radical approach to dealing with the fens, with the aim of neutralizing them as spaces in which both monstrosity and anti-hegemonic heroism can flourish, is to alter them physically: to change them into something which they never were before. This, of course, is what happened with the wholesale drainage of the fens that began in the seventeenth century. Ian Rotheram calls the drainage an act of ecocide and 'England's greatest ecological disaster', ${ }^{37}$ and I tend to agree with him, but it appears to have worked an agricultural miracle. The Dutch engineers turned these marshes into the most fertile arable land in the United Kingdom - though, like Heorot, the modern, drained fenland will not last forever, as peat, which forms most of the subsoil base of the fens, shrinks as it dries out, diminishing the land available for farming and becoming more prone to flooding and topsoil loss through windblow. ${ }^{38}$ The modern fens are still somewhat uncanny - it's always unnerving to drive alongside a river but beneath it at the same time, and they are dark and empty and difficult to navigate - but they are no longer wild. They are constrained, fenced in, bounded, denatured. They have, so people say, been 'reclaimed'. But reclaimed from what, or from whom? They were never ours in the first place. Drainage was an act of imperialist aggression against the land and its indigenous inhabitants, human and non-human. 
It did not happen without resistance, however. There have always been figures, the true fenlanders with one foot in the water, who made their living from eeling, or cutting sedge for thatch, for whom the undrained wetlands were home and even homely, and who reacted strongly against the imposition of drainage, despite its promise of a more profitable and salubrious environment. Once such fenlander was Tiddy Mun.

Tiddy Mun is an obscure figure from Lincolnshire folklore, stories of whom were first recorded in print in 1891. The collector of the Tiddy Mun tales, M. C. Balfour, tells us that his informant was an unnamed old woman, to whom Tiddy Mun was 'a perfect reality', though he found no evidence of knowledge of the legend among her neighbours. ${ }^{39}$ Tiddy Mun is a sort of sprite: an ordinarily benign, even protective spirit, three feet tall, who dwelled in the fen-waters of the Cars, around the Isle of Ancholme. Although his voice, sounding like the cry of the pyewipe, could sound eerie in the night time, locals saw him as an embodiment of the marshland, and credited him with controlling the height of seasonal floods - he did nobody harm until the Dutch arrived to begin delving and pumping. As the waters receded from the bogs, Tiddy Mun lost his habitat, for he had lived down in the still green water, coming out on to dry land only in the evenings, when the mist rose:

For thee know'st, Tiddy Mun dwelt in tha watter-holes doun deep i' tha green still watter, an' a comed out nobbut of evens, whan tha mists rose. Than a comed crappelin out i'tha darklins, limpelty lobelty, like a dearie wee au'd gran'ther, wi' lang white hair, an' a lang white beardie, all cotted an' tangled together; limpelty-lobelty, an' a gowned i' gray, while tha could scarce see un thruff tha mist, an' a come wi' a sound o' rinnin' watter, an' a sough o' wind, an' laughin' like tha pyewipe screech. ${ }^{40}$

Of course, we don't think of Grendel as resembling a 'dearie wee au'd gran'ther' (grandfather), but 'Tiddy Mun's eventide progress out of the water, up through the mist, reminds me more of Grendel's approach to Heorot than many of Beowulf's better-established analogues. The setting is right; the two figures both come creeping under the cover of mist and darkness. And their night-time prowlings are aligned in purpose, too; as the Dutchmen did their work, and his bog-refuges dried up, Tiddy Mun became unhappy - Dutch workers started to disappear in the darkness, never to be heard of again. In effect, Tiddy Mun turns into an ecological terrorist, 
attempting to drive out the alien species that means to deprive him of his home in the name of progress:

Ay, an' for sure, it's ill comes o'crossin Tiddy Mun! For mark ma words! 'Twas first ane, syne anither o'that Dutchies wor gone, clean sperrited away! ... Tiddy Mun a'd fetted un away, an' drooned un i' tha mud holes, wheer tha hadn't drawed off all tha watter! ${ }^{41}$

As Justin Noetzel puts it, 'Tiddy Mun is a metonym for the Fens, and the fen-landscape is a metonym for the natural world; when one piece of this chain of being is nearly destroyed, the whole system reacts and the usually paternal spirit turns vengeful. ${ }^{42}$ I believe that it is productive to think of Grendel as potentially a similar type of being. Tiddy Mun spirits away the Dutchmen who seek to destroy his home; Grendel devours the Danes who impose Heorot's urban sprawl and unendurable noise on to his territory, the mearc that had been marked out by God as being a suitable place of exile for one such as he, far from mankind. ${ }^{43}$ Both of these spirits - for Grendel, let's not forget, is a gast, among other things - can be read as attempting to defend a fenland that provides refuge for them only for as long as it is left in its natural state. Tiddy Mun will harm no one as long as his native waters are high enough. As far as we know, Grendel was dormant and harmless in his fenland exile before Heorot was built next door. The two figures only become aggressive in response to the arrival of invasive outsiders who threaten their homes with ecological disaster - with rendering their land uninhabitable, whether by the literal destruction of the landscape or the imposition of a foreign symbolic order on to it. It is natural that a pyrs will dwell in the fen. Grendel is not, in this story, the one who commits crimes against 'nature' - which is not to say, of course, that he does not commit crimes.

We can read Tiddy Mun and Grendel as two manifestations of a common impulse towards the rejection of foreign bodies from an established, indigenous natureculture - as protective spirits who guard their homelands against the intrusion of outsiders. In both cases, the fenland environments that are under threat are admittedly marginal, foreboding, insalubrious, and seemingly quite unhomely. But they are the proper home of their inhabitants, possessed by right and long custom. The human fenlanders and the monstrous fenlanders alike possess a kinship with the marshes that outsiders view as aberrant and abhorrent. They are adapted to their oikos in a way that 'civilized' people cannot understand or emulate. 
Nicole Guenther Discenza argues that 'Grendel and his mother cross from their own waste, wild space into what had been ordered, civilized space, bringing chaos and destruction into the Danes' world. That is what makes wastelands so threatening., ${ }^{44}$ Discenza is right in her analysis, for this is what the poem Beowulf, which is written from and for the point of view of the 'civilized', wants us to think. But let us reverse these ideas: the Danes (in building Heorot in or close by the Grendelkin's eard) cross from their own ordered, civilized space into what had been the Grendelkin's own space - which was never wasteland from the perspective of its inhabitants - bringing a foreign (notion of) order into Grendel's world. That is what makes civilization so threatening to the natural world and to indigenous peoples whose naturecultures do not conform to the expectations of the civilized. Discenza continues:

Grendel and later his mother come out of the wastes to attack the hall and the men in it. These attacks threaten the whole social fabric of Hrothgar's people, for community life centres upon the hall. They threaten the proper place of Heorot: proper as in property, something that the Danes possess and control; and proper in propriety. ${ }^{45}$

By my reading, however, Heorot threatens (and threatens first) the proper place of the Grendelkin, the eard that is theirs by gift of God, even if that gift is punitive. It is the only home they have.

Viewing Grendel in this way is not an exculpatory move. I do not seek to pardon Grendel's crimes against the Danes, which are real and horrifying. However, looking at Grendel's actions primarily in their ecological context complicates our understanding of his motivations in potentially productive ways. It requires us to take seriously the possibility that the suffering that the Danes inflict upon Grendel with Heorot's noise pollution is real, and really insupportable. Grendel cannot bear the 'dream ... hludne in healle' (joys ... loud in the hall) (88b-89a) that he hears pouring out of the gold-bright building. Grendel's angst arises because he is denied access to such hall-joys because of his family's banishment from the precincts of civilization. But any ecocritical interpretation will tend to be suspicious of any valorized notion of 'civilization'. Critics have tended to view the Grendelkin's own hall beneath or beyond the surface of the mere as somehow parodic of Heorot's true manifestation of civilization; ${ }^{46}$ but the monsters' hall was there first, as far as we know, and it exists in a state of intimacy with its environment - however unpleasant that environment might be to the land-dwellers - in a way that Heorot never can. If we choose, we 
can read Heorot as being the parody: it is all show, no substance, a simulacrum of a heroic hall, built on dreams - the conventional human dreams of our mastery of nature, of the taming of the 'wild', of our separateness from our Others. The Danes cannot defend their hall because it is indefensible. And the Danes cannot, do not, will not try to penetrate the fenny fastness in which the Grendelkin live. They fail to comprehend how anyone could even live there, after all. But Grendel and his mother do live there, have lived there, perhaps would still be living there, had Hrothgar not decided to claim territory in the monsters' eard, their habitat.

We do not know where Beowulf - the poem - truly belongs, either in time or space. I would not use any of the foregoing interpretation as a means of locating the poem's origin in East Anglia or anywhere else - although Sam Newton's work on the possible East Anglian provenance of the text is by no means the least convincing of efforts to localize Beowulf's production. ${ }^{47}$ The faint traces of Grendel in the place-name record that Michael Lapidge was able to assemble would not suggest an East Anglian provenance for this figure: they cluster in western Mercia and Wessex, though Lapidge notes that place names associated with grendel do tend to be found in watery or marshy locales. ${ }^{48}$ In any case, the imagined world occupied by Grendel, Hrothgar, and Beowulf is not and cannot be coterminous with the world of the people who were involved with the poem's production and reception. It is an Anglo-Saxon poem set entirely in a strange pseudo-Scandinavia, after all. If we are to use a sense of place as a way to become more intimate with Beowulf, we encounter the problem of not knowing where to stand or which direction to face. ${ }^{49}$

In their brilliant book Landscapes of Desire, Gillian Overing and Marijane Osborn narrate their sea-journey to Denmark in search of Heorot, or of a place where Heorot made sense to them, in what is by far the most successful psychogeographical approach to Beowulf yet undertaken. ${ }^{50}$ I cannot pretend that Overing and Osborn truly transported me to a place where I felt, as a reader, that I had entered the world of Beowulf, however; in the absence of personal experience of those places, I got no frisson of recognition through Overing and Osborn's prose, no conviction that I would feel at home with the poem in Denmark, that it would make more sense to me if read in that context. I don't feel that I have to travel so far to feel close to Beowulf, to have a sense of belonging to the world of the poem: I just need to look out of the window. Overing and Osborn sought a truer and more meaningful engagement with 
Beowulf in Scandinavia; I find that nowhere else in my experience do I feel as intimate with Beowulf as in the fens of East Anglia.

To me, Beowulf feels like a poem about home. It explores the nature of 'home' - where our homes are, how we build and defend them, the comfort they bring; what happens when we are far from home, homeless, exiled; what happens when we cannot maintain the boundaries by which we seek to define and protect our homes. To me, Beowulf also feels like a poem about $m y$ home. I do not mean by this to make any claim upon Beowulf as belonging to me or to this part of the world - I do not wish to own Beowulf. Reading Beowulf in the fens - and as if Grendel's fens were real fens, our fens, these fens - merely gives me a greater sense of spatial intimacy with the poem than I find elsewhere. This intimacy fosters, and is fostered by, a sense of Grendel and his mother as tragic protagonists rather than demonic antagonists, who are forced into monstrous reprisals by Hrothgar's oppressive (re)claiming of the Grendelkin's own, ancestral land for 'civilization'. My fens, the fens of the twenty-first century, are the product of similar processes of reclamation, of similar denaturings and displacements, of the defeat and banishment of figures like Grendel and Tiddy Mun. But the triumph of 'civilization' over the 'wild' is illusory and temporary, as the fall of Heorot shows. Eventually - and the day may not be far off - the flood defences will fail, the waters will rise, the fen's true identity will reassert itself. We land-dwellers will have to learn once again how to live in intimacy with the fifelcynnes eard. I propose we keep the noise down.

\section{Notes}

1 I am aware that by giving this title to my chapter I would have annoyed the late Eric Stanley, who sadly died before I finished this piece, and who devoted space in print to objecting to the use in Beowulf-scholarship of the term 'Grendelkin' for Grendel, his mother, and any other relations these two figures might have; Eric Stanley, "'A very land-fish, languageless, a monster": Grendel and the like in Old English', in K. E. Olsen and L. A. J. R. Houwen (eds), Monsters and the monstrous in medieval Northwest Europe (Leuven: Peeters, 2001), pp. 79-92. It is true that the term Grendeles $c y n$ or its equivalent is nowhere found in the poem. Nonetheless, I find 'Grendelkin' a useful way of referring to Grendel and his mother that foregrounds the relative normality of their familial relations.

2 Dudley Wright, Vampires and vampirism (London: Rider, 1914), p. 150.

3 Brian J. Frost, The Monster with a thousand faces: guises of the vampire in myth and literature (Madison, WI: University of Wisconsin Press, 1989), p. 36. 
4 M. Bunson, The vampire encyclopedia (New York: Crown, 1993), p. 85. Carol Senf mentions a poem on the same subject, and refers to Ollier's work, but does not give this text the title Vampyre of the fens: Senf, The vampire in 19th-century English literature (Bowling Green, OH: State University Popular Press, 1988), p. 169.

5 The reference to the poem is found in 'Vampyres', Household words, 11 (1855), 43. This article is unsigned in its published form, but Ollier was identified as its author by A. Lohrli, Household words. A weekly journal conducted by Charles Dickens (Toronto: University of Toronto Press, 1973), pp. 389-91.

6 Eugenio Olivares Merino, 'The Old English poem "A Vampyre of the Fens”: a bibliographical ghost', Miscelánea, 32 (2005), 87-102. For the source passage, see Jakob Grimm, Deutsche mythologie (Göttingen: Dietrich, 1835), p. 570.

7 Throughout this chapter, the text of Beowulf is cited from R. D. Fulk, Robert E. Bjork, and John D. Niles (eds), Klaeber's Beowulf, 4th edn (Toronto: University of Toronto Press, 2008) by line number in the text.

8 Olivares Merino, 'The Old English poem "A Vampyre of the Fens"”.

9 Elliott Van Kirk Dobbie (ed.), The Anglo-Saxon minor poems, ASPR 6 (New York: Columbia University Press, 1942), pp. 55-7.

10 Justin T. Noetzel takes it as a given that 'demon is the most appropriate translation of the Old English pyrs', while admitting that the 'term is functionally flexible and can indicate monster, giant, and even wizard'; Noetzel, 'Monster, demon, warrior: St. Guthlac and the cultural landscape of the Anglo-Saxon fens', Comitatus, 45 (2014), 109.

11 Paul S. Langeslag argues that the meaning of mor in Beowulf is 'not immediately transparent', since he considers the terrain surrounding Grendel's mere to be mountainous in places, marshy in others. He suggests that 'mountain, elevated terrain' is both the common and poetic sense of mor in Old English, though he also admits that 'marsh, damp wasteland' is the term's more likely original etymology; Langeslag, 'Monstrous landscape in Beowulf', ES, 96 (2015), 122.

12 William Howarth, 'Imagined territory: the writing of wetlands', New literary history, 30 (1999), 520. I owe my knowledge of this article to Sarah Harlan-Haughey, The ecology of the English outlaw in medieval literature: from fen to greenwood (Abingdon: Routledge, 2016), p. 41.

13 Angus Cameron, Ashley Crandell Amos, Antonette diPaolo Healey et al. (eds), Dictionary of Old English: A to $H$ (Toronto: Dictionary of Old English Project, 2016), s.v. fifel. Langeslag, 'Monstrous landscape', 123, argues that here fifelcynnes eard is a kenning for 'water, sea', an interpretation that I see no pressing justification for, although the formulation does indeed insist upon the wateriness of this landscape.

14 Cameron et al., Dictionary of Old English: A to H, s.v. eard. The primary meanings given for eard (1 and 1.a) are respectively 'dwelling-place' and 
'country, region, native land'. According to the dictionary, sense 1.b.iii, specific to Beowulf, is 'habitat, referring to the habitat of monsters'.

15 Sarah Harlan-Haughey has recently written that 'in the Anglo-Saxon period, we see emotive and ecological connections repeatedly established between exile and wilderness, and especially fen land': Ecology of the English outlaw, p. 23. While I agree with Harlan-Haughey's summary, it is important to my argument that Grendel, though exiled, is no longer living the life of an exile: he has settled in his fenland environment in a way which other outlaw or exile figures never manage.

16 I like the way that Fabienne L. Michelet phrases it: 'Grendel and his mother form a small community and dwell in their own province. Hroðgar's adversary is not a perpetually wandering exile.' Michelet, Creation, migration, and conquest: imaginary geography and sense of space in Old English literature (Oxford: Oxford University Press, 2006), p. 50 .

17 For a description of the geography of Little Downham in the Middle Ages, see Christopher Taylor, "A place there is where liquid honey drops like dew": the landscape of Little Downham, Cambridgeshire, in the twelfth century?', Landscape history, 31 (2010), 5-23. Taylor's title refers to a twelfth-century poem in praise of Little Downham - which was a favoured residence of the bishops of Ely - found in the Libellus Athelwoldi Episcopi, on which see Catherine A. M. Clarke, 'Place, poetry and patronage: the Libellus Athelwoldi verses to Little Downham and their context', Landscape history, 31 (2010), 25-35.

18 On the horrifying affect of this passage, see Arthur G. Brodeur, 'Design for terror in the purging of Heorot', $\mathscr{F E G P , ~} 53$ (1954), 503-13; Michael Lapidge, "Beowulf” and the psychology of terror', in Helen Damico and John Leyerle (eds), Heroic poetry in the Anglo-Saxon period: studies in honor of Fess B. Bessinger, $\mathcal{F}$ r. (Kalamazoo, MI: Medieval Institute Publications, 1993), pp. 373-402.

19 Susan Oosthuizen, The Anglo-Saxon fenland (Oxford: Windgather, 2017).

20 Quoted by E. Mansel Sympson, Lincolnshire (Cambridge: Cambridge University Press, 1913), p. 54; William Shakespeare, King Lear, Act II, scene iv, line 162. On Shakespeare's knowledge and deployment of the fens in his dramas, see Todd Andrew Borlik, 'Caliban and the fen demons of Lincolnshire: the Englishness of Shakespeare's Tempest', Shakespeare, 9 (2013), 21-51.

21 Lindy Brady, 'Echoes of Britons on a fenland frontier in the Old English Andreas', RES, 61 (2010), 672.

22 See Kelly Wickham-Crowley, 'Living on the ecg: mutable boundaries of land and water in Anglo-Saxon contexts', in Clare A. Lees and Gillian R. Overing (eds), A place to believe in: medieval monasticism in the landscape (University Park, PA: Pennsylvania State University Press, 2006), pp. 85-110. 
23 Margaret Gelling and Ann Cole, The landscape of placenames (Donnington: Shaun Tyas, 2014), pp. 20-1; see also Dennis Cronan, 'Old English gelad: “a passage across water”, Neophilologus, 71 (1987), 316-19.

24 On the connection between wolves and outlawry, see Harlan-Haughey, Ecology of the English outlaw, pp. 24-6.

25 After reviewing the evidence of place names with the element hlid (none of which are found in East Anglia), Margaret Gelling concludes that the hleopu found in Beowulf may specifically connote a 'hill with a hollow', which 'provides dead ground, and this could be a lurking place for natural or supernatural enemies'; Gelling, 'The landscape of Beowulf', ASE, 39 (2002), 8-9.

26 Richard Butts, 'The analogical mere: landscape and terror in Beowulf', $E S, 68$ (1987), 21. See also, for example, Harlan-Haughey, Ecology of the English outlaw, pp. 56-63; William Witherle Lawrence, 'The haunted mere in Beowulf', PMLA, 27 (1912), 208-45; William S. Mackie, 'The demons' home in Beowulf', FEGP, 37 (1938), 455-61; Richard J. Schrader, 'Sacred groves, marvellous waters, and Grendel's abode', Florilegium, 5 (1983), 76-84; Geoffrey Russom, 'At the center of Beowulf', in Stephen F. Glosecki (ed.), Myth in early northwest Europe (Tempe, AZ: ACMRS, 2007), p. 234; Langeslag, 'Monstrous landscape'.

27 On mere as a place-name element, see Gelling and Cole, Landscape of placenames, pp. 21-7. As an element in the name of a habitation, mere is widespread throughout England. Intriguingly, Gelling and Cole point out that many mere place names occur in the vicinity of Roman roads or other ancient pathways.

28 Lawrence, 'The haunted mere', 217.

29 Dianne Meredith, 'Hazards in the bog - real and imagined', Geographical review, 92 (2002), 319-20.

30 See Sarah L. Higley, “Aldor on ofre," or the reluctant hart: a study of liminality in "Beowulf”, Neuphilologische Mitteilungen, 87 (1986), 342-53.

31 Andy Orchard, A critical companion to Beowulf (Cambridge: Brewer, 2003), p. 156.

32 Alfred K. Siewers, 'Landscapes of conversion: Guthlac's mound and Grendel's mere as expressions of Anglo-Saxon nation-building', Viator, 34 (2003), 38. Similar comments are made by Nicholas Howe, 'The landscape of Anglo-Saxon England: inherited, invented, imagined', in John Howe and Michael Wolfe (eds), Inventing medieval landscapes: senses of place in western Europe (Gainesville, FL: University Press of Florida, 2002), p. 106.

33 For a survey of theories attempting to explain the light sources in Grendel's lair, see Christopher Abram, 'New light on the illumination of Grendel's mere', $\mathcal{F E G P , ~} 109$ (2010), 198-216.

34 Once again, this suggestion has been made by Fabienne Michelet (Creation, migration, and conquest, p. 50): 'what the monster really opposes 
may be Hroðgar's territorial organization in Denmark, rather than the scop's performance. The fact that the king's dominion impinges on the areas where Grendel rules cannot be excluded, especially not when one bears in mind that Beowulf purges both Heorot and the mere of hostile presences, thereby extending Hroðgar's authority over areas previously under Grendel's control.'

35 For a summary of the medieval sources for Hereward's legend, see John Hayward, 'Hereward the outlaw', Fournal of medieval history, 14 (1988), 293-304.

36 This anecdote is preserved in the twelfth-century Liber Eliensis. See Janet Fairweather (trans.), Liber Eliensis: a history of the Isle of Ely from the seventh century to the twelfth (Woodbridge: Boydell, 2005), p. 210.

37 Ian Rotherham, The lost fens: England's greatest ecological disaster (Stroud: History Press, 2013).

38 David Hall and John Coles, Fenland survey: an essay in landscape and persistence (London: English Heritage, 1994), p. 5.

39 M. C. Balfour, 'Legends of the cars', Folklore, 2 (1891), 145-70. See also Darwin Horn, 'Tiddy Mun's curse and the ecological consequences of land reclamation', Folklore, 98 (1987), 11-15.

40 Balfour, 'Legends of the cars', 150-1.

41 Ibid., 152.

42 Justin T. Noetzel, 'Marshmen and trackless bogs: a cultural history of the English fens', PhD dissertation, Saint Louis University, 2014, p. 192.

43 As Manish Sharma points out, it is possible and fruitful to read mearc in Beowulf as always potentially bearing the double meaning of 'borderland' and 'sign'. The mearc that Grendel and his mother occupy is both a (literal and symbolic) liminal space and a (literal and symbolic) marker of their damnation. Sharma, 'Metalepsis and monstrosity: the boundaries of narrative structure in Beowulf', Studies in philology, 102 (2005), 265.

44 Nicole Guenther Discenza, Inhabited spaces: Anglo-Saxon constructions of place (Toronto: University of Toronto Press, 2017), p. 146.

45 Ibid.

46 Michelet, Creation, migration, and conquest, pp. 105-6; James F. Doubleday, 'Grendel's two halls', Notes and Queries, 58 (2011), 8-10.

47 Sam Newton, The origins of Beowulf and the pre-Viking kingdom of East Anglia (Cambridge: Brewer, 1993).

48 Michael Lapidge, 'Beowulf, Aldhelm, the Liber Monstrorum and Wessex', Studi medievali, 23 (1982), 179-81. The relevant charter clauses are also given as Appendix A.5 in the fourth edition of Klaeber's Beowulf, pp. 293-4.

49 See Alfred Hiatt, 'Beowulf off the map', ASE, 38 (2009), 11-40.

50 Gillian R. Overing and Marijane Osborn, Landscapes of desire: partial stories of the medieval Scandinavian world (Minneapolis, MN: University of Minnesota Press, 1994). 